\title{
MULTIPLE ROLE OF WOMAN'S PERFORMANCE IN INDONESIA: STUDY ON NURSING MEDICAL PERSONNEL
}

\author{
Mauna T. B. Maramis ${ }^{* 1}$ 四, David P. E. Saerang ${ }^{2}$, Adolfina ${ }^{3}$, Victor P. K. Lengkong 4 \\ ${ }^{* 1}$ Department of Economics, Faculty of Economics and Business Sam Ratulangi University, \\ Indonesia \\ 2 Department of Accounting, Faculty of Economics and Business Sam Ratulangi University, \\ Indonesia \\ 3,4 Department of Management, Faculty of Economic and Business Sam Ratulangi University, \\ Indonesia
}

DOI: https://doi.org/10.29121/granthaalayah.v8.i11.2020.2445

Article Type: Research Article

Article Citation: Mauna T. B. Maramis, David P. E. Saerang, Adolfina, and Victor P. K. Lengkong. (2020). MULTIPLE ROLE OF WOMAN'S PERFORMANCE IN INDONESIA: STUDY ON NURSING MEDICAL PERSONNEL. International Journal of Research GRANTHAALAYAH, 8(11), 266-276. https://doi.org/10.29121/granthaa layah.v8.i11.2020.2445

Received Date: 10 November 2020

Accepted Date: 25 November 2020

Keywords:

Multiple Role of Woman

Performance

Nursing Medical Personnel

Work Family Conflicts

Work Stress

Organizational Commitment

Performance

\section{ABSTRACT}

Motivation/Background: In Indonesia, labor force participation is dominated by men while woman's participation is only half. This study was conducted to examine the dual role conflict of women in health workers in Indonesia. The research was conducted on female nurses at the Provincial Hospital of North Sulawesi Province: Prof. Dr. Kandou Manado

Method: The total number of questionnaires distributed was 200 questionnaires, with the response rate was $60 \%$ or 120 respondents. The majority of respondents, are young workers aged 27-36 years, the last education was diploma 3 in nursing, having 3-5 children. To test the hypothesis it was found that a positive and significant relationship between work-family conflict to work stress and organizational commitment to woman's performance in multiple roles was accepted. Another hypothesis relationship tested is rejected.

Results: The results of the study are described in the discussion above which finds various influences and relationships between variables of this study. The dual role of women on performance at work is influenced by various variables.

Conclusions: These results have an impact on hospital organization as well as on future research.

\section{INTRODUCTION}

In today's modern era, the role of women and men tend to be the same in family and in the world of work (Cornwall, 2016). They work together to take care of their family, children, and household chores. It is no longer considered taboo if men take part in childcare, and other household duties. Likewise, the role of women who become career women outside the home is no longer an extraordinary thing. This kind of phenomenon raises the idea that both men and women experience multiple roles in their lives, where they play a role in the family, and play a role in their work outside the home (Gold in, 2006).

(c) 2020 The Author(s). This is an open access article distributed under the terms of the Creative Commons Attribution License, which permits unrestricted use, distribution, and reproduction in any medium, provided the original author and source are credited. 
In Indonesia, the labor force participation rate in 2019 was 2.24 million people. In terms of gender, the labor force participation rate of more than eighty percent (83.18\%) is dominated by men while women's participation is only 55.5\% on an annual basis (Katadata, 2019). The participation of women in the world of work during the last two decades has tended to be stable and only increased very slightly from year to year (Chowdhury et al., 2009). According to a study report from Monash University, and the Indonesian government, the participation of Indonesian women in the world of work is only two-thirds of the participation of men in the world of work (Monash University, 2017).

The entry of women into economic activities has occurred since ancient times. In Indonesia, the role of women in the economy, and development has continued to develop since the Dutch colonial era through the first corporate company in the VOC world in the 16th century, women worked as agricultural laborers in various plantations, and also in mining (Vibriyanti, 2013). One of the causes of increased female labor force participation is due to difficult economic pressures (Sugiyarto et al., 2006). Since Kartini published a collection of poems "light in the darkness or Door duisternis tot licht (Dutch), the Indonesian women's movement has become increasingly prominent, including in the fields of education and the world of work (Nienhof, 1998).

The study that discusses role conflict was first carried out by Kahnet. al., in 1964, (Anafarta, 2010). According to Kahn et al. (1964), role conflict is a pressure that results from difficulties experienced by a person to adapt to other roles. Role conflicts arise from the fact that workers have roles such as working parents and spouses simultaneously, and these roles are conflicting.

Until now, studies related to woman's dual role conflict are still interesting and widely studied in organizational research (Cao et al., 2020; Mukanzi \& Senaji, 2017; Zain \& Setiawati, 2019; Zhao et al., 2011). However, research on the multiple role conflict of women from the perspective of health workers is still lacking in Indonesia, especially in the province of North Sulawesi. For this reason, this study was conducted to examine the dual role conflict of women in health workers in Indonesia. This article is divided into five parts, namely an introduction, research methods, research results, discussion, and conclusions.

\section{CONCEPTUAL FRAMEWORK}

\section{Role Theory}

Role theory is a theory used in the world of sociology, psychology and anthropology which is a combination of various theories, orientations and scientific disciplines. Role theory talks about the term "role" which is commonly used in the world of theater, where an actor in theater must play a certain character. and in that position as a character he is expected to behave in a certain way. The position of an actor in theater is analogous to one's position in society, and both have the same position (Sarlito, 2015: 15).

Role is defined as the characterization carried by an actor in a drama stage, which in the social context, the role is defined as a function that a person carries when occupying a position in the social structure. The role of an actor is a boundary designed by other actors, who both happen to be in one role performance (Suhardono, 1994: 3)

From the above statement, it can be concluded that role theory is a theory that talks about the position and behavior of a person which is expected from him and does not stand alone, but always in relation to the existence of other people who are associated with that person or actor.

\section{Role Aspects}

Biddle and Thomas in Suhardono, (1994: 4) divide the terms in role theory into four groups, namely: People who take part in social interactions; Behavior that appears in these interactions; Position people in behavior; The relationship between people and behavior. Various terms about people in role theory. People who take part in social interactions can be divided into two groups actors, namely people who are behaving according to a certain role. Target (target) or other people, namely people who have a relationship with the actor and their behavior. Actors and targets can be individuals or groups of individuals (groups). The relationship between the group and the group, for example, occurs between a choir (actor) and a listener (target). Usually the term actor is replaced by person, ego, or self. Whereas targets are replaced by the terms alter-ego, ego, or non-self. (Suhardono, 1994: 216).

\section{Behavior in Role}


Biddle and Thomas in Suhardono (1994: 217) divide five indicators of behavior in relation to roles as : Expectation about appropriate behavior, which should be shown by someone who has a particular role. he expectations about this behavior can be general, it can be the expectations of a group of people, and it can also be the expectations of one particular person.

Norm, Secord and Back man in Suhardono, (1994: 218) argue that norms are only one form of hope. Secord and Back man divide the types of expectations: expectations that are predictive (anticipatory), namely expectations about a behavior that will occur and normative expectations (role expectation), namely the necessities that accompany a role. These normative expectations are further divided into two types, hope that is hidden (convert), which is that hope is still there even though it is not spoken, and hope that is open (overt), namely the expressed hope. This type of expectation is called role demand. The role demands through the internalization process can become the norm for the role concerned.

\section{The form of Behavior in the Role (Performance)}

Roles are manifested in behavior by actors. The nature of behavior in this role is real and varies, varying from one actor to another. Such variations in role theory are considered normal and limitless. The role is seen in its form from its basic goal or end result, regardless of how to achieve that goal or outcome. However, it does not rule out the existence of certain ways in a role that are sanctioned by society. A way becomes important in the realization of the role, when it conflicts with other aspects of the role. Thus, an actor is free to determine his own ways as long as it does not conflict with every aspect of the role that is expected of him.

\section{Evaluation and Sanctions}

If it is related to roles, the definition and sanctions are rather difficult to separate the meaning. Biddle and Thomas stated that the assessment and sanctions are based on the expectations of society (other people) about norms. Role assessment in role theory is a positive or negative impression given by society based on the norms that apply to a behavior carried out by actors. Meanwhile, the sanction referred to is the effort made by an actor in maintaining a positive value

\section{Performance Concept}

Performance in an organization is one of the elements that cannot be separated in an organizational institution, be it government institutions or private institutions. Performance as the results of the work function or activity of a person or group in an organization is influenced by various factors to achieve organizational goals within a certain time.

Performance is the result or level of success of a person as a whole during a certain period in carrying out the task compared to various possibilities, such as standard work results, targets or targets or criteria that have been determined in advance and have been mutually agreed. Here are some definitions of employee performance according to experts:

According to Mangkunegara (2014: 67) states that employee performance is the result of work in quality and quantity achieved by an employee in carrying out his duties in accordance with the responsibilities given to him. According to Wibowo (2013: 47), employee performance is an activity of managing organizational resources to achieve organizational goals, just as Hasibuan (2013: 94) states that performance is a result of work achieved by a person in carrying out the tasks assigned to him based on proficiency, experience and sincerity and time.

Performance can also be interpreted as work performance or work implementation or performance results (Suwatno and Donni, 2013: 196). August W. Smith stated that "performance is output derives from processes, human otherwise," which means that performance is the result of a process carried out by humans (in Suwatno and Donni, 2013: 196).

Based on the various definitions above that have been put forward by experts, it can be concluded that the definition of performance is the work of employees achieved in carrying out their duties and responsibilities in order to achieve the main goals of the organization as determined by the organization.

\section{Factors Affecting Performance}

Performance is often a problem in every organization or company, a decline in performance does not just happen without cause. According to Sedarmayanti (2013: 229), factors that influence performance include: Compensation, motivation, organizational culture, work environment, work stress, discipline and competence. 
Meanwhile, according to Sedarmayanti (2013: 229), there are several factors that can affect employee performance including the following: compensation, motivation, organizational culture, work environment, work stress, discipline and competence.

Furthermore, according to Gibson, Ivancevich and Donnely (2010:217) suggest that there are three groups of variables as performance factors in organizations, Individual variables, including: (a) abilities and skills (physical), (b) background (family, social level, and experience), and (c) demographics (age, origin, gender), Organizational variables, including: (a) resources, (b) leadership, (c) rewards, (d) structure, and (e) job design and Psychological variables include: (a) mental / intellectual, (b) perception, (c) attitude, (d) personality, (e) learning, and (f) motivation.

\section{Dimensions and Performance Indicators}

Performance can be measured and seen from indicators related to the performance of the employees themselves. According to Robbin in Mangkunegara (2014: 75) suggests that the dimensions and performance indicators can be measured, namely as follows:

\section{Quality of Work}

Quality of work is how well an employee does what should be done. The dimensions of work quality are measured using three indicators, namely: beauty, accuracy, work results, work quantity

Work quantity is how long an employee works in one day. This work quantity can be seen from the work speed of each employee. The dimensions of the quantity of work are measured by two indicators, namely: speed, ability, responsibilities

Responsibility for work is awareness of the employee's obligation to carry out the work given by the company. The responsibility dimension is measured using two indicators, namely: work results, make decisions, cooperation.

The willingness of employees to participate with employees or other employees vertically and horizontally both inside and outside of work so that the results of the work are getting better. The dimension of cooperation is measured using two indicators, namely: cooperation, cohesiveness, initiative

Initiatives from within company members to do work and solve problems at work without waiting for orders from superiors or showing responsibility in work that has become the obligation of employees or employees. Initiative dimensions are measured using one indicator, namely the ability to solve problems without waiting for orders from superiors. So, it can be concluded that employee performance indicators can be measured starting from the dimensions of work quality, work quantity, responsibility, cooperation, and the initiatives undertaken by the employees themselves.

While Gomes (2000: 142) in a different version suggests performance criteria based on descriptions of specific behaviors, namely: quantity of work (namely the number of work results obtained in a specified time period\}, quality of work (achieved based on the requirements of conformity and readiness), job knowledg (the breadth of knowledge about work and skills), creativeness (the authenticity of ideas that arise and actions to solve problems that arise). cooperative (the willingness to cooperate with other people to fellow members of the organization, dependability (awareness and trusworthiness in attendance and work completion), initiative, (the spirit to carry out new tasks and with great responsibility and personal qualities (include personality, leadership, hospitality, and personal integrity).

Gomes (2000: 142) states that quantitative performance measures such as production units and sales volume produce relatively consistent measurements. Subjective criteria, such as attitude, creativity, and cooperation, result in less consistent measurement, depending on who is evaluating, and how the measurement is carried out ".

\section{Job Stress}

Job stress is an adaptive response, limited by individual differences and psychological processes, namely the consequences of any activity (environment), situation or external event that imposes excessive psychological or physical demands on a person where the individual is located. positive stress is called stress while excessive stress and is detrimental is called distress. In an employee's job that is given excessive loads or a job that is not in accordance with their abilities, they will experience stress in carrying out their work, stress here is a way that the employee can contribute to a satisfactory work for the company.

Work stress is the physical and psychological pressure that a person feels when facing obstacles, demands, or extraordinary opportunities. Every employee has the opportunity to experience work stress depending on the workload he is facing. Gibson Ivancevich Donnelly (2010: 16) states that stress as an adaptive response, mediated 
by individual debates or psychological processes, is a consequence of any activity (environment), situation, or external event, which imposes excessive psychological or physical demands on a person. .

In addition, Gibson Ivancevich, Grenberg (in Setiyana, 2013) argues that job stress is a very difficult construct to define, stress at work occurs in a person, where someone runs from problems, since some workers bring the level of work to a tendency to stress. Job stress as a combination of sources of stress at work, individual characteristics, and stressors outside the organization. Job stress is a stressful condition that creates a physical and psychological imbalance, which affects an employee's emotions, thought processes and condition.

Stress as a response to adaptation which is influenced by individual differences and psychological processes, as a consequence of environmental actions, situations or events that make too much psychological and physical demands on a person. Thus it can be concluded that work stress arises because of environmental demands and the responses of each individual in dealing with it can be different.

According to Greenberg (in Setiyana, 2013) Job Stress is a construct that is very difficult to define, stress at work occurs to a person, where someone runs from problems, since some workers bring job levels to the tendency of work stress as a combination of sources of stress at work, individual characteristics, and stressors outside the organization. Job stress is a stressful condition that creates a physical and psychological imbalance, which affects the emotions, thought processes, and conditions of an employee. In general, job stress is grouped into individual stressors and organizational stressors are individual assessors (attitudes, characteristics, physical characteristics, interests and motivation, experience, age, gender, education) and organizational stressors (physical and occupational factors, consisting of: work methods, conditions and design of work equipment, spatial planning and the physical environment).

\section{MATERIALS AND METHODS}

\section{Subject and Settings}

The research was conducted on female nurses at the Provincialospital of North Sulawesi Province Prof. Dr. Kandou Manado, with a population of 270 people. The total number of questionnaires distributed was 200 questionnaires, but only 120 completed questionnaires where the response rate was 60\%, with an accidental sampling technique.

\section{Questionnaire Development and Data Analysis}

The variables in the research instrument were developed from various references, including multiple roles performance of Gomes (2011), work-family conflict (Frone et al., 1992, 1994), family-work conflict (Boles et al., 2001; Frone et al., 1992), job stress (Ivancevich et al., 2013), and organizational commitment (Greenberg \& Baron, 2010). The measuring scale used a 5 point Likert psychometric scale from strongly disagree to strongly agree. Based on the results of the research instrument test before the research was carried out, it was found that results were valid and reliable so that the research questionnaire could be continued at the next stage for data analysis. Data were analyzed using path analysis.

\section{RESULTS AND DISCUSSIONS}

\section{Results}

The characteristics of research respondents from the 120 respondents studied were the majority of respondents, namely: aged 27-36 years (73.33\%), the last education was diploma 3 in nursing (42.50\%), having 3-5 children $(81.60 \%)$.

Table 1: Percentage and Frequency Distribution Related to the Individual Characteristics of the Study Participants

\begin{tabular}{|c|c|c|}
\hline Individual Characteristics & $\mathrm{f}$ & $\%$ \\
\hline Age & & \\
\hline $20-26$ years old & 32 & 26.66 \\
\hline 27-36 years old & 88 & 73.33 \\
\hline Education Level & & \\
\hline
\end{tabular}


Multiple Role of Woman's Performance in Indonesia: Study on Nursing Medical Personnel

\begin{tabular}{|c|c|c|}
\hline Nursing Vocational School & 47 & 39.16 \\
\hline Nursing Associate Degree III & 51 & 42.5 \\
\hline Nursing Associate Degree IV & 15 & 12.5 \\
\hline Nursing Bachelor & 7 & 5.83 \\
\hline Number of Child & & \\
\hline $1-2$ & 15 & 12.5 \\
\hline $3-5$ & 98 & 8.6 \\
\hline$>5$ & 7 & 5.8 \\
\hline Total & 120 & 100 \\
\hline
\end{tabular}

Source: processed data (2020)

The value of R-square (R2) is 0.402. This figure means that the contribution of the influence of the Work-Family Conflict, Family-Work Conflict, Work Stress, and Organizational Commitment to the Performance of Multiple Roles Women is $40.2 \%$. Meanwhile, $59.8 \%$ is influenced by other variables not included in the model. This means that the variability of the level of Organizational Commitment is only $40.2 \%$ which can be explained by the variables of WorkFamily Conflict, Family-Work Conflict, Work Stress, and Organizational Commitment while 59.8\% is explained by other variables outside the model studied. The following Figure 1 shows the empirical research model based on the results of the path analysis.

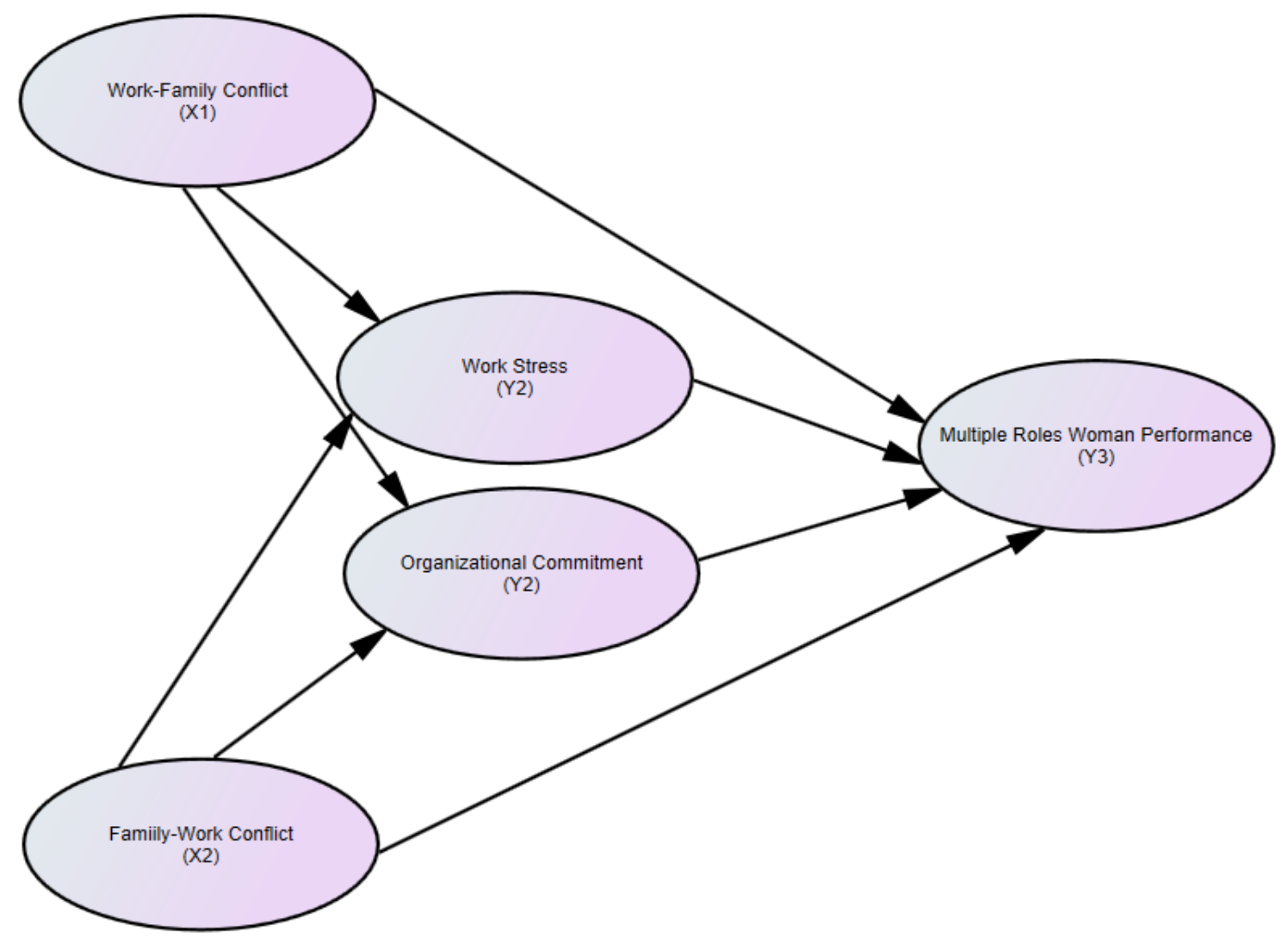

Figure 1: Path Analysis Empirical Model

Based on the results of the path analysis that has been carried out, the results of the research hypothesis test are summarized in Table 2.

Table2: Summary of Empirical Hypothesis Test Results 
Mauna T. B. Maramis, David P. E. Saerang, Adolfina, and Victor P. K. Lengkong

\begin{tabular}{|c|c|}
\hline Hypothesis Test & Explain \\
\hline Work-Family Conflict has a significant positive effect on work stress & $\begin{array}{c}\text { Accepte } \\
\text { d }\end{array}$ \\
\hline The family-work conflict has a significant positive effect on work stress & Rejected \\
\hline Work-Family Conflict has a significant negative effect on organizational commitment & Rejected \\
\hline The family-work conflict has a significant negative effect on organizational commitment & Rejected \\
\hline Work-Family Conflict has a significant negative effect on the Performance of Multiple Roles Women & Rejected \\
\hline Family-Work Conflict has a significant negative effect on the Performance of Multiple Roles Women & Rejected \\
\hline Job Stress Has a Significant Negative Effect on the Performance of Multiple Roles Women & Rejected \\
\hline Organizational Commitment Has a Significant Positive Effect on Women's Performance in Multiple & $\begin{array}{c}\text { Accepte } \\
\text { Roles }\end{array}$ \\
\hline
\end{tabular}

Source: processed data (2020)

\section{Discussion}

The obtained data is analyzed using descriptive statistics to determine respondents characteristics, perceptions of entrepreneurship, the attractiveness for entrepreneurship, and the driving factors for entrepreneurship. Table 1 presents general description of respondents. The majority of respondents is female (56\%) compared to male (44\%). Based on observations, the population of students in North Sulawesi is dominated by female students. Most respondents are between 21-22 years old (71.2\%). When completing studies in college, most respondents are interested working in BUMN (28.4\%), entrepreneur (25.2\%), and civil servants $(22.7 \%)$. Related to the occupation of parents, most fathers work in the private sector (35.2\%), civil servants (30\%) while most of the mothers $(28.0 \%)$ working as entrepreneurs, $26.4 \%$ working as civil servants.

Table3: General Description of Respondents

\begin{tabular}{|c|c|c|}
\hline Gender & Frequency & Percentage (\%) \\
\hline Male & 110 & 44 \\
\hline Female & 140 & 56 \\
\hline 20 & 12 & 4,8 \\
\hline 21 & 88 & 35,2 \\
\hline 22 & 90 & 36,0 \\
\hline 23 & 47 & 18,8 \\
\hline $24-26$ & 13 & 5,2 \\
\hline \multicolumn{2}{|c|}{ Occupation in Demand } \\
\hline Civil Servant & 57 & 22,8 \\
Private & 54 & 21,6 \\
BUMN (State Own Enterprise) & 71 & 28,4 \\
Entrepreneur & 63 & 25,2 \\
Others & 5 & 2,0 \\
\hline \multicolumn{2}{|c|}{ Father's Occupation } \\
\hline Not mention & 6 & 2,4 \\
BUMN (State Own Enterprise) & 4 & 1,6 \\
Businessman & 10 & 4,0 \\
Civil Servant & 75 & 30,0 \\
Private & 88 & 35,2 \\
Entrepreneur & 67 & 26,8 \\
\hline \multicolumn{2}{|c|}{ Mother's Occupation } \\
Bot mention & 40 & 16,0 \\
BumN (State Own Enterprise) & 1 & 0,4 \\
Businessman & 16 & 6,4 \\
Civil Servant & 66 & 26,4 \\
\hline
\end{tabular}


Multiple Role of Woman's Performance in Indonesia: Study on Nursing Medical Personnel

Source: Data processed, 2018

\section{Perceived Entrepreneurial Motivation}

The perceived entrepreneurial of respondents is measured by the 5 point Likert Scale (5-strongly agree; 4agree; 3-neither agree nor disagree; 2-disagree; and 1-strongly disagree). Table 2 presents the average score of student entrepreneurial motivation, that is, the average of respondent interested in entrepreneurship (4.35) but it decreases (4.05) when asked for the seriousness of pursuing employment as an entrepreneur. It can be caused by obstacles perceived by respondents such as capital problem, fear of taking risk, and hesitation to start.

Table 2: Average Score of Motivation to Entrepreneurship

\begin{tabular}{|c|c|c|}
\hline Items & Mean & Standard Deviation \\
\hline Interest in entrepreneurship & 4.35 & 0.747 \\
\hline Seriousness of being an entrepreneur & 4.05 & 0.832 \\
\hline \multicolumn{3}{|l|}{ Pull Factors } \\
\hline Freedom to develop ideas & 4.42 & 0.655 \\
\hline Desire to high achievement & 4.40 & 0.733 \\
\hline Desire to status recognition & 3.66 & 0.991 \\
\hline For self development & 4.40 & 0.641 \\
\hline Desire to large income & 4.56 & 0.657 \\
\hline Average & 4.29 & 0.735 \\
\hline \multicolumn{3}{|l|}{ Push Factors } \\
\hline Difficulty to get job & 3.07 & 1.106 \\
\hline Not satisfy with other jobs & 3.21 & 1.013 \\
\hline Family economic pressure & 3.11 & 1.127 \\
\hline No other choices & 2.62 & 1.062 \\
\hline Other jobs are not promising enough salary & 3.31 & 1.111 \\
\hline Average & 3.06 & 1.084 \\
\hline
\end{tabular}

Source: Data processed, 2018

Pull factors are positive factors attracting for entrepreneurship including independence, achievement, recognition, personal development, and personal wealth. Push factors are negative factors encouraging entrepreneurship including unemployment, job insecurity, and no other alternatives. As seen in table 2 , the average score for pull factors is 4.29 higher than push factors (3.06). It means that students' motivation to entrepreneurship is triggered by positive factors that attract entrepreneurship than negative factors that force entrepreneurship. There are four interesting factors for entrepreneurship indicated by the average score above the average; those are the desire for large income (4.56), freedom to develop ideas (4.42), the desire for high achievement, and for selfdevelopment (4.40). Negative factors that encourage entrepreneurship are other jobs are not promising enough salary (3.31), not satisfy with other jobs (3.21), family economic pressure (3.11), and difficulty to get job (3.07).

\section{Gender-Based Motivational Factors}

Gender-based differences in motivational factors is tested with the Independent Samples T-Test as presented in table 3. Test result shows that there are no significant gender-based differences regarding to pull factors and push factors that encourage entrepreneurship.

Table 4: Gender-Based Differences in Motivational Factors

\begin{tabular}{|c|c|c|c|}
\hline \multirow{2}{*}{ Motivational Factors } & \multicolumn{2}{|c|}{ Mean } & \multirow{2}{*}{ Sig. (t-test) } \\
\cline { 2 - 3 } & Male & Female & Sig.
\end{tabular}


Mauna T. B. Maramis, David P. E. Saerang, Adolfina, and Victor P. K. Lengkong

\begin{tabular}{|c|c|c|c|}
\hline Pull factors: & & & \\
Independence & 4.45 & 4.40 & 0.587 \\
Achievement & 4.42 & 4.38 & 0.672 \\
Recognition & 3.64 & 3.67 & 0.782 \\
Personal development & 4.38 & 4.42 & 0.628 \\
Personal wealth & 4.55 & 4.58 & 0.693 \\
\hline Push factors: & & & \\
Unemployment & 3.06 & 3.08 & 0.916 \\
Dissatisfaction & 3.17 & 3.24 & 0.588 \\
Family economy pressure & 3.06 & 3.14 & 0.582 \\
No other alternative & 2.69 & 2.57 & 0.378 \\
Job insecurity & 3.29 & 3.32 & 0.830 \\
\hline
\end{tabular}

Source: Data processed, 2018

\section{CONCLUSIONS AND RECOMMENDATIONS}

The purpose of this study is to determine the motivation of students for entrepreneurship. The finding of this study is that respondents generally have a high interest for entrepreneurship but there is an indication that respondents are not serious about making entrepreneurs their career goals. It is indicated by declining average score when asked about the seriousness of being an entrepreneur. It is possible that someone has a high motivation for entrepreneurship but at the same time is faced with various obstacles to actualize that desire.

The constraints can come from within individual such as fear of taking business risk, doubt, and lack of skill. It is supported by the results of this study in which entrepreneurship is ranked second as BUMN (State Own Enterprise) is the target of in-demand jobs after completing education. This finding is consistent with Campbell (1992) and Segal et al. (2005) that being an entrepreneur is often rejected as the career choice because it is faced with everyday life and work situations that are full of uncertainty, related difficulties in starting a business, management, and bear responsibility for business risks. Oi and Ahmad (2012) found the same result where the perception of students in Malaysian University is very low to make entrepreneurs as the career choices.

Motivational factors perceived by respondents as the motivating factors for entrepreneurship are pull factors compared to push factors. This finding means that respondents are interested in entrepreneurship because of independence, that is the desire to set their own work time, want to find freedom, achievement, personal development, and personal wealth. The result of this study is consistent with the previous studies such as Keeble et al. (1992), Birley and West head (1994), Orhan and Scott (2001), Pistrui et al. (2001). This finding is also in line with Sloka et al. (2014) that most important motivational factors to start business are independence and personal wealth. Zwan et al. (2016) identified business owners whether they start a business because of opportunity or necessity factors.

$\mathrm{t}$ turns out that their finding showed that business owners are involved in entrepreneurship because they see business opportunities rather than necessity. Necessity entrepreneurs seem to relate to individual dissatisfaction with previous employment conditions, which is different from opportunity entrepreneurs who voluntarily leave their previous jobs because they see business opportunities.

This finding also showed no significant gender-based difference in motivational factors. Men and women have the same perception, namely they have same motivation for entrepreneurship because of pull factors rather than push factors. In contrast, Adom and Williams (2012) studied on informal businesses found that women tend to be driven by necessity compared to men who are more triggered by opportunity factors.

\section{SOURCES OF FUNDING}

This research received no specific grant from any funding agency in the public, commercial, or not-for-profit sectors. 
Multiple Role of Woman's Performance in Indonesia: Study on Nursing Medical Personnel

\section{CONFLICT OF INTEREST}

The author have declared that no competing interests exist.

\section{ACKNOWLEDGMENT}

This research was funded independently by researchers, and all research teams contributed directly to the completion of this research. Therefore, the authors thank you for the help and motivation that has been given.

\section{REFERENCES}

[1] Anafarta, N. 2010. The Relationship between Work-Family Conflict and Job Satisfaction: A Structural Equation Modeling (SEM) Approach. International Journal of Business and Management, 6(4), 168-177. https://doi.org/10.5539/ijbm.v6n4p168

[2] Boles, J. S., Howard, W. G., \& Donofrio, H. H. 2001. An Investigation into the Inter-Relationships of WorkFamily Conflict, Family-Work Conflict And Work Satisfaction. Journal of Managerial Issues, 13(3), 376-390. https://www.jstor.org/stable/40604357

[3] Cao, J., Liu, C., Guandong, W., Zhao, X., \& Jiang, Z. 2020. Work-Family Conflict and Job Outcomes for Construction Professionals: The Mediating Role of Affective Organizational Commitment. International Journal of Environmental Research and Public Health, 17(4), 1-24. https://doi.org/10.3390/ijerph17041443

[4] Cornwall, A. 2016. Women's Empowerment: What Works? Journal of International Development, 28(3), 342359. https://doi.org/10.1002/jid.3210

[5] Frone, M. R., Rusell, M., \& Cooper, M. L. 1992. Antecedents and outcomes of work-family conflict: Testing a model of the work-family interface. Journal of Applied Psychology, 77(1), 65-78. https://doi.org/10.1037/0021-9010.77.1.65

[6] Frone, M. R., Rusell, M., \& Cooper, M. L.1994. Relationship between job and family satisfaction: Causal or noncausal covariation? Journal of Management, 20(3), 565-579. https://doi.org/10.1016/01492063(94)90003-5

[7] Goldin, C. 2006. The Quiet Revolution That Transformed Women's Employment, Education, and Family. The American Economic Review, 96(2), 1-21. https://doi.org/10.1257/000282806777212350

[8] Gomes, F. C.2011. Human Resource Management. ANDI.

[9] Greenberg, J., \& Baron, R. (2010). Behavior in Organization (10th ed.). Prentice Hall.

[10] Ivancevich, J. M., Konopaske, R., \& Matteson, M. T. (2013). Organizational Behavior and Management (10th ed.). McGraw Hill Education.

[11] Kahn, R. L., Wolfe, D. M., Quinn, R. P., Snoek, J. D., \& Rosenthal, R. A. 1964. Organizational stress: Studies in role conflict and ambiguity. John Wiley \& Sons.

[12] Katadata. 2019. Tingkat Partisipasi Tenaga Kerja Masih Didominasi Laki-laki: Tingkat Partisipasi Angkatan Kerja Menurut Jenis Kelamin (Februari 2018-Februari 2019) [Big Data]. Katadata.Co.Id. https://databoks.katadata.co.id/datapublish/2019/05/07/tingkat-partisipasi-tenaga-kerja masihdidominasi-laki-laki

[13] Khuong, M. N., \& Yen, V. H. 2016. Investigate the Effects of Job Stress on Employee Job Performance-A Case Study at Dong Xuyen Industrial Zone, Vietnam. International Journal of Trade, Economics and Finance, 7(2), 31-37. https://doi.org/10.18178/ijtef.2016.7.2.495

[14] Malik, M. S., Awan, A. G., \& Ain, Q. 2015. Role of Work Family Conflict on Organizational Commitment and Organizational Effectiveness. Arabian Journal of Business and Management Review, 3(1), 115-126. https://doi.org/10.12816/0011653

[15] Monash University. 2017. Women's Economic Participation in Indonesia. A study of gender inequality in employment, entrepreneurship, and key enablers for change. Australia Indonesia Partnership for Economic Governance.

https://www.monash.edu/business/cdes/our-research/publications/publications2/Womens-economicparticipation-in-Indonesia-June-2017.pdf 
[16] Mukanzi, C. M., \& Senaji, T. A. 2017. Work-Family Conflict and Employee Commitment: The Moderating Effect of Perceived Managerial Support. SAGE Open, July-September, 1-12. https://doi.org/10.1177/2158244017725794

[17] Netemeyer, R. G., Maxham, J. G., \& Pullig, C. 2005. Conflicts in the Work-Family Interface: Links to Job Stress, Customer Service Employee Performance, and Customer Purchase Intent. Journal of Marketing, 69(2), 130143. https://doi.org/10.1509/jmkg.69.2.130.60758

[18] Nienhof, A. 1998. The changing lives of Indonesian women; Contained emancipation under pressure. Journal of the Humanities and Social Sciences of Southeast Asia and Oceania, 154(2), 236-254. https://doi.org/10.1163/22134379-90003897

[19] Nohe, C., Michel, A., \& Sonntag, K. 2013. Family-work conflict and job performance: A diary study on boundary conditions and mechanisms. Journal of Organizational Behavior, 35(3), 339-357. https://doi.org/10.1002/job.1878

[20] Riana, I. G., Wiagustini, N. L. P., Dwijayanti, K. I., \& Rahayana, I. G. 2018. Managing Work Family Conflict and Work Stress through Job Satisfaction and Its Impact on Employee Performance. Jurnal Teknik Industri, 20(2), 127-134. https://doi.org/10.9744/jti.20.2.127-134

[21] Sabil, F., Abu, H., Kasuma, J., \& Lizzan, N. 2016. Identifying Work-Family Conflict among Nurses: A Qualitative Study. Conference: BE-Ci. 3rd International Conference on Business and Economics, Selangor, Malaysia. https://doi.org/0.15405/epsbs.2016.11.02.11

Sedoughi, Z., Sadeghi, M., Shaharki, S. K., Anari, S. H. S., \& Amiresmaili, M. 2016. The relation of work, family, and life quality of nurses working at teaching hospitals of Kerman-Iran. Bali Medical Journal, 5(1), 110-115. https://doi.org/10.15562/bmj.v5i1.280

[22] Sugiyarto, G., Oey-Gardiner, M., \& Triaswati, N. 2006. Labor Markets in Indonesia: Key Challenges and Policy Issues. In Labor Markets in Asia (Jesus Felipe, Rana Hasan, pp. 301-366). Palgrave Macmillan. https://doi.org/10.1057/9780230627383_6

[23] Triaryati, N. 2003. Pengaruh Adaptasi Kebijakan Mengenai Work Family Issue Terhadap Absen Dan Turnover (The Effect of Policy Adaptation Regarding Work Family Issue on Absence and Turnover). Journal of Management and Entrepreneurship, 5(1), 85-96.

http://jmk.petra.ac.id/repository/transfer/MAN03050108.pdf

[24] Vibriyanti, D. 2013. Gender Inequality in Economic Participation: Sakernas Data Analysis 1980-2013. Jurnal Kependudukan Indonesia, 8(1), 1-16.

https://doi.org/10.14203/jki.v8i1.18

[25] Wang, X., Liao, J., Xia, D., \& Chang, T. 2010. The impact of organizational justice on work performance: Mediating effects of organizational commitment and leader-member exchange. International Journal of Manpower, 31(6), 660-677.

https://www.researchgate.net/publication/227429289_The_impact_of_organizational_justice_on_work_per formance_Mediating_effects_of_organizational_commitment_and_leader-member_exchange

[26] Zain, A. N. D., \& Setiawati, T. 2019. Influence of Work Family Conflict and Job Satisfaction on Medical Employee Performance through Organizational Commitment. Review of Integrative Business and Economics Research, 8(1), 1-19. http://buscompress.com/uploads/3/4/9/8/34980536/riber_8-1_k18-141_1-19.pdf

[27] Zhao, X. R., Qu, H., \& Ghiselli, R. 2011. Examining the relationship of work-family conflict to job and life satisfaction: A case of hotel sales managers. International Journal of Hospitality Management, 30(1), 46-54. https://doi.org/10.1016/j.ijhm.2010.04.010. 